\title{
Marketable Yields of Fresh-market Tomatoes Grown in Plastic and Hairy Vetch Mulches
}

\author{
Aref A. Abdul-Baki ${ }^{1}$, John R. Teasdale ${ }^{2}$, Robert W. Goth ${ }^{3}$, and \\ Kathleen G. Haynes ${ }^{4}$ \\ U.S. Department of Agriculture, Agricultural Research Service, The Henry A. \\ Wallace Beltsville Agricultural Research Center, Sustainable Agricultural \\ Systems Laboratory, Beltsville, MD 20705
}

Additional index words. Lycopersicon esculentum, Vicia villosa, Alternaria solani, no-till production, sustainable agriculture, cover crop mulches, early blight

\begin{abstract}
The use of mulches in vegetable production is undergoing a radical change away from high-input, nonrenewable resources, such as plastic, to the use of highresidue organic mulches from cover crops. The purpose of this study was to compare the marketable yield of various fresh-market tomato genotypes when grown under plastic and hairy vetch mulches. In 1996 and 1997, 12 fresh-market tomato genotypes were evaluated for yield on the North Farm of the Beltsville Agricultural Research Center (BARC), MD in a randomized split-plot design. Tomatoes were grown in conventional tillage plastic mulch (PM) and no-till hairy vetch mulch (HVM). Early blight, caused by Alternaria solani Sor., developed naturally in the plots both years and was recorded over time. All 12 genotypes were susceptible to early blight. Area under the disease progress curve (AUDPC) was calculated for each plot. AUDPC was similar both years. However, the year $\times$ mulch and year $\times$ mulch $\times$ genotype interactions were significant for AUDPC. Adjusting yields for AUDPC had a minimal effect on the data. Overall, yields were similar in PM and HVM both before and after adjusting for AUDPC. However, the mulch $\times$ genotype interaction was significant. The yield of eight of the genotypes was significantly higher in the HVM than in the PM system both years, ranging from $12 \%$ to $57 \%$ higher in 1996 and $10 \%$ to $48 \%$ higher in 1997 . There was no yield difference for one genotype in HVM as compared to PM. The yield in the remaining three genotypes was either higher under HVM than PM or there was no difference. As yields from the HVM system are greater than or equal to yields in the PM system, soil compaction is reduced and nitrogen inputs are lower. The no-till HVM system is at least as good, and often better, than the conventional tillage PM system.
\end{abstract}

Until the 1980s, many vegetable production systems in the U.S. utilized high-input conventional practices that used tillage, plastic mulches (PM), commercial fertilizers, and pesticides (Shennan, 1992). These conventional tillage systems typically begin with a primary deep tillage operation, followed by some secondary tillage for seed bed preparation, and cultivation during the crop growing season. These systems produced economically feasible yields, but little attention was given to environmental protection and conservation of natural resources. Recent concerns about reducing environmental pollution, depleting non-renewable natural resources, and rising production costs have become strong economic and social forces responsible for the development of alternative production systems to address these problems (Abdul-Baki and Teasdale, 1993: Griffith et al., 1986; Kelly et al., 1995; Shales, 1989). As a result, new environmentally friendly production concepts

Received for publication 17 July 2001. Accepted for publication 8 Nov. 2001

${ }^{1}$ Plant Physiologist.

${ }^{2}$ Plant Physiologist.

${ }^{3}$ Plant Pathologist (retired).

${ }^{4}$ Plant Geneticist. were introduced. These included conservation tillage practices, as defined by Sumner et al. (1981), to reduce soil erosion and compaction (Sumner et al., 1981); replacement of PM with high-residue mulches from cover crops and utilization of the cover crops to reduce erosion, fix nitrogen $(\mathrm{N})$, recycle nutrients, and reduce weed pressure (Abdul-Baki and Teasdale, 1997b); and use of crop rotation and integrated pest management (IPM) practices to minimize chemical pest control (Sumner et al., 1986).

These alternative production systems had been used in the production of major field crops for many decades prior to their introduction into vegetable production. Attainment of economic yields, adequate weed suppression, and availability of equipment suitable for these production methods, such as no-till seeders, no-till transplanters, highspeed flail mowers and rollers, were prerequisites for these alternative production systems to become applicable to vegetable crops.

The shift from conventional to alternative cropping systems caused major changes in the edaphic and crop environments. No-tillage reduced soil erosion and soil compaction (Coolman and Hoyt, 1993). The cover crops served as mulches, effectively suppressed weeds, provided a favorable environment for the growth of microorganisms, and raised the level of organic matter content in soils (Doran, 1980). These factors improved soil tilth in the upper-most zone of the soil profile, which is the root zone for most vegetable crops (Pieters, 1927). Residues from these cover crops also reduced the amount of commercial fertilizers needed for subsequent crops (Shennan, 1992; Morse, 1999; Teasdale and Abdul-Baki, 1998).

Several studies have been reported on the effects of soil management on crop yields and pest control. Beste (1979) evaluated the effect of tillage on several vegetables. He observed that no-tillage enhanced the yields of early direct-seeded tomatoes, whereas yields of snap beans, lima beans, watermelons and sweet corn were comparable to conventional tillage. In the no-tillage system, no seed bed preparation is needed other than opening the soil for the purpose of placing the seed at the intended depth (Sumner, et al., 1981). There is usually no cultivation during crop production. Mullins et al. (1980) compared yields of snap beans and lima beans under tillage and no-tillage following barley. They found that tillage did not affect yields of snap beans, whereas lima bean yields were higher with conventional tillage. More recently, Abdul-Baki and Teasdale (1997a) reported that snap beans, grown in a no-till residue from a hairy vetch mulch (HVM), yielded 50\% to $100 \%$ higher than those grown conventionally and without cover crops. They attributed the lower yields in the conventional system to soil erosion and washing away of nutrients under heavy rain. Likewise, tomatoes (Abdul-Baki, 1993; AbdulBaki and Teasdale, 1993; Abdul-Baki et al., 1996a; 1996b) and bell peppers (Abdul-Baki et. al, 1999) grown in no-till residues of hairy vetch or crimson clover yielded equal or higher than those grown in bare soil or PM. The effects of no-tillage and cover crops on pests were not investigated in these studies. Herrero et al. (2001) reported that cover crops maintained the yields and suppressed weeds in notill processing tomatoes as compared to conventionally tilled fallow controls. Early season weed suppression in rye/vetch and triticale/vetch plots was similar to herbicide-treated fallow plots but weeds were less effectively suppressed later in the growing season.

Coolman and Hoyt (1993) investigated the effects of reduced tillage systems on the soil environment. They concluded that vegetable crops managed with reduced tillage generally offered better water holding capacity, improved infiltration (Griffith et al., 1986), and allowed non-mobile nutrients to accumulate in the soil surface layer (Robbins and Voss, 1991).

The impact of cultural practices on incidences of diseases in vegetables has not been extensively investigated. Sumner et al. (1980, 1981) reviewed the effects of reduced tillage and multiple cropping on plant diseases in temperate, semi-arid, arid, and subtropical climates. They concluded that tillage practices directly influenced physical and chemical properties of the soil, soil moisture, and temperature, root growth and nutrient uptake, and populations of vectors of plant pathogens. 
These factors in turn may have influenced the viability or resistance of the host. They further concluded that leaving plant debris on the surface or partially buried in the soil may allow numerous pathogens to over-winter, or survive until the next crop is planted, but conditions favorable for biological control of plant pathogens may also be increased.

Gudmestad et al. (1978) reported that plowing wheat residues $26 \mathrm{~cm}$ deep increased stem and stolon lesions on potato caused by Rhizoctonia solani compared with disking or plowing $13 \mathrm{~cm}$ deep. Organic matter on the soil surface inhibited the survival or infection potential of $R$. solani. Phatak (1992) and Sumner et al. (1996) concluded that $R$. solani is probably influenced more by tillage practices than any other soil-borne pathogen because the fungus survives in colonized plant debris in the soil. Deep turning $(20-30 \mathrm{~cm})$ the soil with a moldboard plow effectively removed the fungal propagules from the top $10-15 \mathrm{~cm}$ of the root zone and buried them deep where, because of higher $\mathrm{CO}_{2}$ concentration, their population declined. They found that diseases caused by Pythium sp. and those caused by Fusarium sp. were not influenced by tillage.

McKeown et al. (1998) evaluated foliar and fruit diseases in tomatoes grown for six years on the same site using conventional and strip tillage. The strip tillage treatments included rye (Secale cereale L.), wheat (Triticum aestivum L.), and perennial ryegrass (Lolium perenne L.) as cover crops and a twoyear rye-tomato rotation. They reported that bacterial speck/spot symptoms on foliage were significantly greater in strip-tilled than in conventionally-tilled plots during the last three years of the six-year experiment and concluded that no major trends in incidence and severity of bacterial and fungal diseases were noted under conventional vs. strip tillage.

Yield and disease incidence data among vegetable cultivars of the same species in response to changes in production practices are lacking. In one report, Abdul-Baki et al. (1996a) compared yield, fruit processing quality, and leaf necrosis (a physiological disorder) of 10 commercial cultivars of processing tomatoes grown in bare soil, PM, and residue from HVM. They reported that yield was higher, fruit were heavier, and leaf necrosis was less in HVM than in bare soil or PM. They also reported major yield differences among cultivars within the production systems. For example, cv 'Spectrum' yielded 54\% higher in HVM than in bare soil or PM, whereas cv 'Nema 140 ' yielded only $12 \%$ higher in HVM than in PM. Differences in foliar diseases among cultivars in response to cultural practices were noted but no data were recorded.

The objective of this study was to determine the effect of two production systems, a conventional system that utilizes tillage and PM, and an alternative system that utilizes a HVM from cover crop and no tillage, on marketable yields of 12 genotypes of freshmarket tomatoes. Data on early blight, a serious disease of tomatoes in the New England, Atlantic and Central states (U.S. Dept. of Agriculture, 1972), caused by the fungus $\mathrm{Al}$ - ternaria solani (Ell. and G. Martin) Sorauer, were also collected with the objective of finding any differences in severity of the disease between PM and HVM as well as among genotypes in the same mulch.

\section{Materials and Methods}

The field plots. The experiments were conducted in Summer 1996 and Summer 1997 on the North Farm of the Beltsville Agricultural Research Center, Beltsville, Md. The soil is a Keyport fine loam (clayey, mixed, mesic Acqruic Hapluduet) with 2\% slope. Two production systems were used: 1) a conventional system characterized by tillage, black PM, and fertilizer from a commercial source; and 2) an alternative system characterized by no-tillage, high-residue HVM (Vicia villosa Roth) cover crop, and some commercial $\mathrm{N}$ fertilizer to supplement the $\mathrm{N}$ fixed and recycled by hairy vetch.

The experimental design was a split-plot design, where the whole-plot factor was type of mulch (plastic vs. hairy vetch), and the subplot factor was tomato genotype (12 genotypes). Each sub-plot consisted of four raised beds with the inner two containing experimental plants while the outer two were border rows. Each experimental bed was $4.8 \mathrm{~m}$ long $\times$ $1.5 \mathrm{~m}$ wide. The two inner beds comprised one replicate in which the 12 genotypes were randomly planted, using 20 plants per genotype (10 plants per bed) and two-plant spaces between one genotype and the next genotype. Two plants on each end were border plants. Data were collected on the middle six plants in each bed, for a total of 12 plants per replication. Plants were spaced $0.4 \mathrm{~m}$ within the row and $1.5 \mathrm{~m}$ between rows.

Preparing the plots and managing the cover crops. Details on preparing the plots and seeding the cover crop were published elsewhere (Abdul-Baki et al., 1996). In both years, the field had been planted into sweet corn the previous summer. The corn plants were chopped in late Aug. and incorporated into the soil by roto-tilling to a depth of $15 \mathrm{~cm}$ two weeks prior to forming raised beds. No additional soil management or cultivation of any kind was performed on the no-tillage plots at any time throughout the tomato growing season. Hairy vetch was seeded in the cover crop plots on 20 Sept. of 1995 and 1996 at $45 \mathrm{~kg} \cdot \mathrm{ha}^{-1}$ using a Brillion seeder (Brillion Iron Works, Brillion, Wisc.). Raised beds for the PM treatment were prepared in late April by disking, forming the raised beds, and laying the drip line and PM. Two days before transplanting the tomatoes, $0.25 \mathrm{~m}^{2}$ areas of aboveground hairy vetch were harvested and ovendried to obtain biomass yield. The hairy vetch was mowed with a high-speed flail mower (Hesston Corp., Oregon, Ill.).

Tomato seed, sources and seedling production. Seeds of 'Sunbeam' were made available by Asgrow Seed Co., Kalamazoo, Mich., and seeds of 'Brandy Wine' were purchased from Johnny's Selected Seeds, Albion, Maine. Seeds of the remaining 11 genotypes were kindly provided by Randolf Gardner, North
Carolina State Univ., Raleigh, N.C. Seeds were sown in the greenhouse on 9 Apr. 1996 and on 2 Apr. 1997 following a procedure described by Abdul-Baki and Teasdale (1993). Five-week-old seedlings were transplanted into the field using a Holland punch-type planter (Holland Co., Holland, Mich.), which opens a hole $6 \times 6 \mathrm{~cm}$ wide and $9 \mathrm{~cm}$ deep, drops the seedling, adds $50 \mathrm{~mL}$ of water into the hole, and packs the soil around the plant.

Management of the tomato crop. Details on managing the tomato crop are described elsewhere (Abdul-Baki et al., 1996). Briefly, plots were irrigated every other day through the drip lines. Colorado potato beetle was controlled using Bt-based insecticides. Tetrachloroisohthalonitrile (chlorothalonil) was applied at $2.3 \mathrm{~L} \cdot \mathrm{ha}^{-1}$ six times in 1996 beginning 26 June, and seven times in 1997 beginning 28 June, at $\approx 1$-week intervals. The last two applications in each year included kocide $\left[\mathrm{Cu}(\mathrm{OH})_{2}\right]$ at $3 \mathrm{~kg} \cdot \mathrm{ha}^{-1}$. In addition, 4-Amino-1,1-dimethylethyl-3-(methylthio)1,2,4-triazin-5(4H)-one (metribuzin) at 0.56 $\mathrm{kg} \cdot \mathrm{ha}^{-1}$ was applied as a post-emergence herbicide 3 weeks subsequent to transplanting.

Fertilizer applications were based on soil tests performed in the fall of the previous year. Soil tests in both years revealed a very high level of $\mathrm{P}$ and a high level of $\mathrm{K}$. Therefore, only $\mathrm{K}$ was incorporated into the soil at 56 $\mathrm{kg} \cdot \mathrm{ha}^{-1}$ at the time the beds were formed. Application of $\mathrm{N}$ was based on earlier research findings for optimum requirements in these plots (Abdul-Baki et al., 1997). These findings showed that the optimum $\mathrm{N}$ rates for tomatoes grown on the conventional (PM plus tillage) and HVM systems were 190 and $90 \mathrm{~kg} \cdot \mathrm{ha}^{-1}$, respectively. This recommendation was based on aboveground biomass of $\mathrm{HV}$ of $4 \mathrm{t} \cdot \mathrm{ha}^{-1}$ with $3.1 \%$ to $3.3 \% \mathrm{~N}$ content. Above-ground biomass yields of hairy vetch reported in this study are in that range. Therefore, the PM and the HVM treatments received $\mathrm{N}$ as ammonium nitrate at 190 and $90 \mathrm{~kg} \cdot \mathrm{ha}^{-1}$, respectively. The fertilizer was delivered through the drip system in seven equal portions at 10 -d intervals, starting 1 week after transplanting.

Tomato fruits were harvested every $5 \mathrm{~d}$ at the breaker to firm-ripe stage from 23 July to 28 Aug. Marketable yields were determined following an established procedure (AbdulBaki et al., 1997).

Early blight severity. Early blight occurred naturally in the field even though fungicides were sprayed weekly. To assure the accuracy of pathogen identification, lesions from random leaf samples were incubated until the organism sporulated, and it was identified as Alternaria solani.

Plants were evaluated for early blight damage on 5 and 22 Aug. 1996 and 29 July, 13 and 27 Aug. 1997. Eight plants per replicate were individually evaluated and scored on a scale of 0 to 9 where: $0=$ no disease observed; $1=$ one to ten lesions per plant with the total of $<1 \%$ of leaf area infected (LAI); $2=11$ to 50 lesions per plant which is 1 to $3 \% \mathrm{LAI} ; 3=3$ to $5 \%$ LAI; $4=6$ to $11 \% \mathrm{LAI} ; 5=12$ to $24 \% \mathrm{LAI} ; 6$ $=25$ to $49 \%$ LAI; $7=50$ to $74 \%$ LAI; $8=75$ 
to $87 \% \mathrm{LAI}$; and $9=88$ to $100 \% \mathrm{LAI}$. Scores from the eight plants were averaged to the nearest 0.1 for each date.

Statistical analysis. Percent disease was plotted against the disease rating scale using the lower boundary of the interval, and average values of disease ratings to the nearest 0.1 were interpolated to percent disease. Area under the disease progress curve (AUDPC) was calculated for each plot (Shaner and Finney, 1977). The more rapidly disease progresses during the growing season, the higher the AUDPC value; lower AUDPC values are indicative of slow disease progression. Yield and AUDPC data were analyzed using the general linear models procedure (SAS Institute, 1987); least square means were computed for yield and AUDPC, and least square means for yield between mulching systems for each genotype were compared using the pdiff option. In this analysis, years and replicates were treated as random effects; mulch and genotypes were treated as fixed effects. The expected mean squares were calculated and the appropriate F tests were constructed. Satterthwaite's approximation (1946) was used to synthesize an F test of genotypic effects. Yield data were also adjusted for AUDPC by running an analysis of covariance, with AUDPC as the covariate (SAS Institute, 1987). The type III mean squares are reported since they represent the adjustment for the covariate.

\section{Results and Discussion}

There were significant differences in yield between years (Table 1). The average yields in 1996 and 1997 were 82.0 and $70.1 \mathrm{t} \cdot \mathrm{ha}^{-1}$, respectively (Tables 2, 3). Lower yields in 1997 were attributed to two nights of frost $\left(-1{ }^{\circ} \mathrm{C}\right) 3 \mathrm{~d}$ after transplanting. Plants in both tillage systems were damaged by frost and the damage was more pronounced in the PM. The impact of this damage was exhibited by reduced plant vigor and yield.

There was no significant mulching system effect on overall yields (Table 1). The average yield in PM and HVM was 69.2 and $82.9 \mathrm{t} \cdot \mathrm{ha}^{-1}$, respectively (Tables 2,3 ). Although these differences are as great as the differences between years, the lack of significance may be due to the fact that the F test was constructed with only one degree of freedom in both the numerator and the denominator.

However, the year $\times$ mulch interaction on yield was significant (Table 1). In 1996 when plants were not damaged by frost after transplanting, there was a difference of $15.8 \mathrm{t} \cdot \mathrm{ha}^{-1}$ in HVM over PM (Table 2), whereas in 1997 there was a $11.5 \mathrm{t} \cdot \mathrm{ha}^{-1}$ gain in HVM over PM (Table 3).

There were significant differences among genotypes for yield (Table 1). In order of highest to lowest yield averaged over the 2 years in $\mathrm{t} \cdot \mathrm{ha}^{-1}$, they were NC-92191 (87.4), 'Mountain Supreme' (85.1), NC-9380 (83.5), 'Majesty' (83.4), 'Sunbeam' (81.8), EF-50 (81.8), 'Sunpride' (79.6), 'Mountain Spring' (75.7), 'Sunbrite' (74.1), 'Brandy Wine' (72.2), XP-10045 (71.9), and NC-24E (36.0).
There were significant mulch $\times$ genotype interactions for yield (Table 1). In 1996, ten of the genotypes yielded significantly more in HVM than PM (Table 2) and in 1997, nine genotypes yielded significantly more in HVM than PM (Table 3 ). In both years, the rest of the genotypes yielded equally in both mulching systems. The increased yields in HVM over PM ranged from $12 \%$ to $57 \%$ in 1996 and from $10 \%$ to $48 \%$ in 1997 (Tables 2 and 3).

There were also significant year $\times$ genotype and year $\times$ mulch $\times$ genotype interactions for yield (Table 1). The differences in yield in Mountain Supreme, Majesty, NC-9380, and Sunbrite varied greatly depending on mulching system and year (Tables 2 and 3). The differences in yield among the remaining genotypes were fairly consistent between years and mulching systems.
The rep (year), year $\times$ mulch and year $\times$ mulch $\times$ genotype interactions were significant for AUDPC (Table 1). AUDPC was more severe in PM than in HVM in 1996 (473.6 vs. 407.6) and much more severe in PM than in HVM in 1997 (489.6 vs. 244.6). None of the other sources of variation were significant. Adjusting the yield analysis using AUDPC as a covariate (Table 1) produced negligible changes in the interpretation of the data even though AUDPC explained a significant portion of the variation (data not shown).

One disadvantage of HVM over PM was an average delay of fruit maturity by $5 \mathrm{~d}$ in 1996 and $11 \mathrm{~d}$ in 1997. However, the yield advantages enjoyed by most of the genotypes in HVM over PM system can be attributed to major plant growth differences (Teasdale and Abdul-Baki, 1997). Plants in HVM produced

Table 1. Mean squares from the analysis of variance on yield $\left(t \cdot h a^{-1}\right)$, area under the disease progress curve (AUDPC), and analysis of covariance on yield adjusted for AUDPC.

\begin{tabular}{lrccc}
\hline \hline & & \multicolumn{2}{c}{ Mean squares } & \\
\cline { 3 - 4 } Source & d.f. & Yield & AUDPC & Yield Adj AUDPC \\
\hline Year & 1 & $6820^{* *}$ & 258,768 & $6784^{* *}$ \\
Rep (year) & 6 & $455^{* *}$ & $109,997^{* *}$ & $441^{* *}$ \\
Mulch & 1 & 8939 & $1,161,904$ & 5844 \\
Year $\times$ mulch & 1 & $225^{* *}$ & $383,879^{* *}$ & $306^{* *}$ \\
Error a & 6 & 20 & 12,660 & 18 \\
Variety & 11 & $2969^{* *}$ & 96,411 & $2899^{* *}$ \\
Mulch $\times$ variety & 11 & $347^{*}$ & 35,548 & $354^{*}$ \\
Year $\times$ variety & 11 & $288^{* *}$ & 45,535 & $278^{* *}$ \\
Year $\times$ mulch $\times$ variety & 11 & $89^{* *}$ & $54,690^{*}$ & $89^{* *}$ \\
Error b & 132 & 16 & 25,848 & 15 \\
AUDPC & 1 & $107^{* *}$ & & \\
\hline
\end{tabular}

*,** Significant at $P \leq 0.05$ or 0.01 .

Table 2. Mean yield $\left(\mathrm{t} \cdot \mathrm{ha}^{-1}\right)$ for 12 tomato genotypes grown in 1996.

\begin{tabular}{lcrcr}
\hline Variety & Plastic & Vetch & Vetch vs. plastic & Mean \\
\hline Brandy Wine & 65.3 & 92.1 & $* *$ & 78.7 \\
EF-SO & 78.4 & 107.4 & $* *$ & 92.9 \\
Mountain Spring & 76.5 & 85.6 & $* *$ & 81.1 \\
Mountain Supreme & 67.9 & 106.7 & $* *$ & 87.3 \\
Majesty & 87.6 & 84.9 & NS & 86.2 \\
NC-24E & 28.6 & 37.2 & $* *$ & 32.9 \\
NC-92191 & 89.8 & 102.3 & $* *$ & 96.0 \\
NC-9380 & 78.6 & 104.9 & $* *$ & 91.7 \\
Sunbeam & 82.9 & 88.2 & NS & 85.5 \\
Sunbrite & 81.5 & 91.4 & $* *$ & 86.4 \\
Sunpride & 74.6 & 95.1 & $* *$ & 84.8 \\
XP-10045 & 77.6 & 83.2 & & 80.4 \\
Mean & 74.1 & 89.9 & & 82.0 \\
\hline ss, ${ }^{* *}$ Nonsignificant or significant at $P \leq 0.05$ or 0.01. & &
\end{tabular}

Table 3. Mean yield $\left(\mathrm{t} \cdot \mathrm{ha}^{-1}\right)$ for 12 tomato genotypes grown in 1997.

\begin{tabular}{lcccr}
\hline Variety & Plastic & Vetch & Vetch vs. plastic & Mean \\
\hline Brandy Wine & 53.1 & 78.5 & $* *$ & 65.8 \\
EF-SO & 59.4 & 81.9 & $* *$ & 70.7 \\
Mountain Spring & 67.0 & 73.7 & $*$ & 70.3 \\
Mountain Supreme & 74.7 & 91.1 & $* *$ & 82.9 \\
Majesty & 75.6 & 85.6 & $* *$ & 80.6 \\
NC-24E & 34.1 & 42.0 & $* *$ & 39.0 \\
NC-92191 & 74.8 & 82.7 & $* *$ & 78.7 \\
NC-9380 & 71.4 & 79.0 & $* *$ & 75.2 \\
Sunbeam & 75.5 & 80.8 & NS & 78.1 \\
Sunbrite & 64.1 & 61.5 & NS & 61.8 \\
Sunpride & 63.3 & 85.5 & $* *$ & 74.4 \\
XP-10045 & 61.2 & 65.7 & NS & 63.4 \\
Mean & 64.3 & 75.8 & & 70.1 \\
\hline Ns, ***Nonsignificant or significant at $P \leq 0.05$ or 0.01 & &
\end{tabular}

Ns, *, **Nonsignificant or significant at $P \leq 0.05$ or 0.01 . 
higher leaf area ratio, had greater leaf duration, and higher leaf chlorophyll content (Abdul-Baki, 1993) than those in PM. Consequently, tomatoes grown in HVM outgrew and out-yielded those grown in PM because of increased partitioning to leaf area (Teasdale and Abdul-Baki, 1997). This advantage is exhibited by HVM over PM even when the plants in HVM received $47 \%$ of the fertilizer $\mathrm{N}$ applied to those in PM. Nitrogen requirements must have been met as a result of fixation and recycling by hairy vetch. The hairy vetch cover crop yielded an average of about $4 \mathrm{t} \cdot \mathrm{ha}^{-1}$ of above-ground biomass in both years. Additionally, the cover crop has been reported to recycle macro- and micronutrients to support vigorous plant growth (Abdul-Baki et al., 1996; Abdul-Baki and Teasdale, 1997b).

Early blight developed in all plots in both years even though the plots were sprayed with a fungicide at weekly intervals. However, there were significant year $\times$ mulch differences in AUDPC, with more disease recorded under PM than HVM. Early blight is primarily a disease of senescing plant tissue. In 1996, 50\% of the marketable yield for that year was reached on 11 and 16 Aug. for plants grown under PM and HVM, respectively. This difference may be attributed to higher soil temperature and less plant vigor under PM than under HVM. It seems likely that the more vigorous growth that occurred in the plants under HVM, as compared to those under PM, may have slowed the development of early blight by delaying senescence. In 1997, the plants were stressed by early frost. The stress resulted in $50 \%$ of the marketable yield attained on 4 and 15 Aug. in plants grown under PM and HVM, respectively. Stress affected plants under PM more than those under HVM as exhibited by severely reduced leaf mass yield and early maturity. Unfortunately, no detailed plant maturity ratings were taken; Such ratings could have been used to estimate the relative effect of plant maturity on AUDPC. Additional studies in plots with no fungicide application and limited fungicide applications will be needed to determine if the HVM system has the potential to reduce disease development as compared to the PM system. However, under a normal fungicide application regime, our data suggest that HVM has the potential to decrease early blight pressure for most tomato genotypes at least in some years. The potential economic benefit of these variable fungicide application regimes should be undertaken simultaneously with the yield and disease evaluation in the future. These data also suggest the possibility of breeding tomato genotypes specifically for a given mulching system.

\section{Literature Cited}

Abdul-Baki, A. 1993. Evaluation of processing tomato varieties in a sustainable agricultural system using hairy vetch mulch. Proc. 24th Annu. Mtg., The Mid-Atlantic Veg. Workers Conf. Nov. 9-10, 1993. Univ. of Delaware, Newark. 23:59-64.

Abdul-Baki, A. and J.R. Teasdale. 1993. A notillage tomato production system utilizing hairy vetch and subterranean clover mulches. HortScience 28:106-108.

Abdul-Baki, A., J.R. Stommel, A.E. Watada, J.R Teasdale, and R.D. Morse. 1996a. Hairy vetch mulch favorably impacts yield of processing tomato. HortScience 31:338-340.

Abdul-Baki, A., J.R. Teasdale, R. Korcak, D.J. Chitwood, and R.N. Huettel. 1996b. Fresh-market tomato production in a low-input alternative system using cover crop mulch. J. Amer. Soc. Hort. Sci. 31:65-69.

Abdul-Baki, A. and J.R. Teasdale. 1997a. Snap bean production in conventional tillage and in no-till hairy vetch mulch. HortScience 32:1191-1193.

Abdul-Baki, A. and J.R. Teasdale. 1997b. Sustainable production of fresh-market tomatoes and other summer vegetables with organic mulches. U.S. Dept. Agr., Agr. Res. Serv., Farmers' Bul. No. 2279, Washington, D.C.

Abdul-Baki, A., J.R. Teasdale, and R.F. Korcak. 1997. Nitrogen requirements of fresh-market tomatoes on hairy vetch and black polyethylene mulch. HortScience 32:217-221.

Abdul-Baki, A., R.D. Morse, and J.R. Teasdale. 1999. Tillage and mulch effects on yield and fresh fruit mass of bell pepper (Capsicum annum L.). J. of Veg. Crop Production 5:43-58.

Beste, C.E. 1979. No tillage planted vegetable crops. 9th Int. Congr. Plant Prot., 5-11 Aug., Washington, D.C., Abstr. No. 136.

Coolman, R.M. and G.D. Hoyt. 1993. The effects of reduced tillage on the soil environment. HortTechnology 3:143-145.

Doran, J.W. 1980. Soil microbial and biochemical changes associated with reduced tillage. Soil Sci. Soc. Amer. J. 44:765-771.

Griffith, D.R., J.V. Mannaring, and J.F. Box. 1986. Soil and moisture management with reduced tillage, p. 19-55, In: M.A. Sprague and G.B. Triplett (ed.). No-tillage and surface-tillage agriculture. Wiley, New York.

Gudmestad, N.C., J.E. Huguelet, and R.T. Zink. 1978. The effect of cultural practices and straw incorporation into soil on Rhioctonia disease of potato. Plant Disease Rptr. 62:985-989.

Herrero, E.V., J.P. Mitchell, W.T. Lanini, S.R. Temple, E.M. Niyao, R.D. Morse, and E. Campiglia. 2001. Use of cover crop mulches in no-till furrow irrigated processing tomato production system. HortTechnology 11:43-48.

Kelly, T.C., Y.C. Lu, A. Abdul-Baki, and J.R. Teasdale. 1995. Economics of a hairy vetch mulch system for producing fresh-market toma- toes in the mid-Atlantic region. J. Amer. Soc. Hort. Sci. 120:854-860.

McKeown, A.W., R.F. Corkauskas, J.W. Potter, and L. Van Driel. 1998. Long-term evaluation of cover crop and strip tillage on tomato yield, foliar diseases, and nematode populations. Canadian J. of Plant Sci. 78:341-348.

Morse, R. D. 1999. No-till vegetable productionIt's time is now. HortTechnology 9:373-379.

Mullins, C.A., F.D. Tompkins, and W.L.Park. 1980. Effects of tillage methods on soil nutrients distribution, plant nutient absorption, stand, and yields of snap beans and lima beans. J. Amer. Soc. Hort. Sci. 105:591-593.

Phatak, S.C. 1992. An integrated sustainable vegetable production system. HortScience 27:738-741.

Pieters, A.J. 1927. Green manuring: Principles and practices. Wiley, London.

Robbins, G.R. and R.D. Voss. 1991. Phosphorus and potassium stratification in conservation tillage systems. J. Soil and Water Cons. 46:298300.

Satterthwaite, F.E. 1946. An approximate distribution of estimates of variance components. Biometrics Bul. 2:110-114.

SAS Institute. 1987. SAS/STAT Guide for Personal Computers, Version 6 ed. SAS Inst., Cary, N.C.

Schales, F.D. 1989. Survey results on plastic mulch use in the United States, p. 95. Proc. 21st Nat'l. Agr. Plastics Congr., Orlando, Fla., 5-9 Mar. 1989.

Shaner, G. and R.E. Finney. 1977. The effect of nitrogen fertilization on the expression of slow mildewing-resistance in 'Knox' wheat. Phytopathology 67:1051-1056.

Shennan, C. 1992. Cover crops, nitrogen recycling and soil properties in semi-irrigated vegetable production systems. HortScience 27: 749-753.

Sumner, D.R., E.D. Threadgill, C.C. Dowler, S.C. Phatak, D. Smittle, J. Young, G.A. Mitchell, and A.W. Johnson. 1980. Tillage practices, populations of soil fungi, and root diseases in irrigated, multiple cropping sequences. Phytopathology 71:259. (Abstr.)

Sumner, D.R., B. Doupnik, Jr., and M.G. Boosalis. 1981. Effects of reduced tillage and multiple cropping on plant diseases. Ann. Rev. Phytopathol. 19:167-187.

Sumner, D.R., E.D. Threadgill, D.A. Smittle, S.C. Phatak, and A.W. Johnson. 1986. Conservation tillage and vegetable diseases. Plant Dis. 70:906911.

Teasdale, J.R. and A. Abdul-Baki. 1997. Growth analysis of tomatoes in black polyethylene and hairy vetch production systems. HortScience 32:659-663.

Teasdale, J.R. and A. Abdul-Baki. 1998. Comparison of mixtures vx. monocultures of cover crops for fresh-market tomato production with and without herbicide. HortScience 33:11631166.

U.S. Department of Agriculture. 1972. Tomato diseases and their control. Agr. Handbook No. 203, Agr. Res. Service, Washington, D.C. 